\title{
The Events in 1990
}

Abstract This chapter deals with the continuation of the conflict and the breaking up of Yugoslavia. By 1990, Federal Yugoslavia was unpopular. Most Yugoslavs wanted to move from communism to democracy, yet they associated federation with communism and Serb domination.

Keywords Yugoslavia $\cdot 1990 \cdot$ Communism $\cdot$ Serbia

Outside of Serbia, almost all wanted decentralising reforms, but most Serbs disliked the decentralisation that had already occurred. ${ }^{1}$ The League of Communists of Yugoslavia collapsed on 20-22 January 1990, when Slovenia and Croatia left the Congress that was held. When SFRY (Social Federal Republic of Yugoslavia) collapsed, SPS (Socialist Party of Serbia) stressed that where Serbs were in majority, they should be able to say that they wanted to remain in the Yugoslavian state. In March 1990, a new Serbian constitution was ratified, limiting the autonomy

\footnotetext{
${ }^{1}$ Mann (2005, p. 366).
}

(C) The Author(s) 2017 
of Vojvodina and Kosovo. ${ }^{2}$ This was a strike against Yugoslavia as an entity. No new president could be elected for Yugoslavia in the early 1990s because Milošević controlled the republics and blocked the sole presidential candidate all according to the parliamentary system of Yugoslavia. The position Bosnia, Croatia, Macedonia and Slovenia voting for the presidential candidate, and Serbia, Vojvodina, Kosovo and Montenegro voting against. ${ }^{3}$ This process has been described as a slide from centralism towards confederalism, which is true. This change of the political field also had an impact on the military. It resulted in the JNA (Jugoslovenska Narodna Armija, i.e. The Army) partly redefining its role and eventually its conception of itself. ${ }^{4}$

It is interesting to note that the republics that were soon to break away, Slovenia and Croatia, were at this stage still in favour of holding Yugoslavia together, even if it looked as if later they would separate from the federation. If that presidential election had had a positive result, with the installation of a president, there would still have been accepted constitutional structures in place to lean back on during the partitioning process, which would have led to a more peaceful course of events. As it turned out, relatively undeveloped areas like Kosovo (and even Montenegro might be regarded as undeveloped) came to stifle the desire to move in that direction in more developed areas like Croatia and Slovenia-and in comparison especially with Kosovo, in the more industrialised Bosnia. This created what is usually known as a democratic deficit, albeit the term is more appropriately used in connection with established democracies. Nevertheless, the situation generated a feeling of inherent injustice and illegitimacy towards the constitution of Yugoslavia. This ought to have contributed to strengthening the desire of Croatia and Slovenia to go their own way. Meanwhile in Bosnia-after the elections of 1990-extremism came in focus in Bosnia. For example, Karadic's Serbian Democratic Party (SDS; Srpska Demokratska Stranka)

\footnotetext{
${ }^{2}$ Kerenji $(2005$, p. 367).

${ }^{3}$ Donia and Fine (1994, p. 214). Dyker and Vejvoda (1996), claim that Croatia for the most part blocked all possibility of a federal election. p. 19.

${ }^{4}$ Dulić and Kostic (2010, p. 1064).
} 
slid from a moderate line towards a more extreme one. ${ }^{5}$ After the weak results in the election, SDS became more nationalistic speaking of the western borders of Serbia and saying that they wanted peace, but the current status was more like capitulation than peace. ${ }^{6}$

The ones who had actively supported a united Yugoslavia were marginalised by the obvious hopelessness of trying to elect a federal president, and the surge of confederalistic or even separatist rhetoric. Expressed in theoretical terms, this marginalisation can be viewed as a loss of capital, the ability to influence the political field being reduced, while those with agendas other than a united Yugoslavia gained wider room for manoeuvre. Milošević and SPS presented themselves as being a more moderate alternative to many other parties from 1990 onwards. ${ }^{7}$ By the SPS victory with $45.8 \%$ on 9 December 1990, the membership had risen largely due to new members. The SPS went to election with slogans of peace and prosperity, in opposition to more nationalistic alternatives. Serb communists moved towards nationalism in order to prevent giving the opposition monopoly of it. The restructured field forced restructuring on the actors, and the space of possibilities for them changed accordingly.

Kosovo was the start for an expression of opinion along Serbian lines which then surfaced in other parts of Yugoslavia. The events in Kosovo in 1990 signalled to the whole of Yugoslavia, and certainly to Slovenia and Croatia, that Milošević not only practiced nationalist rhetoric but also had a coordinated policy line. On 8 of September, the Serbian constitution was changed, drastically reducing the autonomy previously enjoyed by Vojvodina and Kosovo. ${ }^{8}$ This upsets the legitimacy of the

\footnotetext{
${ }^{5}$ Gagnon (2004, p. 50).

${ }^{6}$ Stojanovic (2000, p. 469). May 1991 was the time when Mirko Petrovic talked about the western borders.

${ }^{7}$ Gagnon $(2004$, p. 46). In the 1992 election, Milosevic was challenged by Milan Panic in selling the moderate line. Ibid, Gagnon noting a working paper of his.

${ }^{8}$ Udovicki and Torov (1997, p. 92$)$.
} 
political system and thus made way for alternate ways of carrying out politics. It should be noted in this connection that there were a number of background factors that made Milošević's nationalist agenda viable, but it was his political strategy that was the initiating and driving force. A similar question is whether a German war of revenge would have taken place had it not been for Hitler. The answer is probably given, the harsh Versailles treaty. Would the Holocaust have taken place without Hitler? The answer is no, at least no if the Nazis did not come to power but some other right-wing movement with no specific anti-semitic agenda. ${ }^{9}$ The comparison is made not to put Milošević on a level with Hitler, which would be outrageous, but to show that structural change often is difficult, regardless of which actors are involved. Both the Second World War and the partitioning of Yugoslavia were examples of this phenomenon. On the other hand, the ethnic cleansing in Yugoslavia and the Holocaust during World War II would be hard to imagine without actors that at least had the same type of agenda as the two leaders named above.

Both the Serbian and Bosnian nationalist movements repeatedly referred to the Second World War, in order to create a sense of continuity for and lend legitimacy to their own movements. This approach is relatively common, regardless of whether it concerns politics, science, business or other areas. Institutions or people who had high reputations in the past in the eyes of a particular group will still be of current value and also used because of that very value. It is a question of identifying oneself with the symbolic capital of the actor or institution concerned and thereby strengthening one's own position at the same time. ${ }^{10}$ Tudjman was an accomplished politician of the Realpolitik genre and may have seen that these Nazi references were favourably regarded by the Croatian diaspora. ${ }^{11}$ Many of these had fled Yugoslavia after the Second World War, and even if new generations had come, the nationalistic master narrative sprung from the Ustasha Croatia was strong in the diaspora. The same can be said about the Serbs to some extent. Serbia started to run a satellite TV channel of its own, mostly because

\footnotetext{
${ }^{9}$ This argument is first made by the nazi-German dissident Sebastian Haffner. Haffner (1991, p. 216).

${ }^{10}$ Gunneriusson (2002, p. 38).

${ }^{11}$ Dulić $(2009$, p. 263).
} 
they wanted to reach the Serbian diaspora. Many of those had emigrated because of rightist Chetnik sympathies in the generation before or even the same generation. ${ }^{12}$ They were disposed to be affected by the propaganda. Both diasporas had power not only because of their ability to work on the opinion abroad which is a form of PSYOPs by proxy, but also that they had more financial assets than those in the former Yugoslavia had at the time.

It was of no great concern that these movements might not gain legitimacy in the eyes of the international community in general since their policies were geared for those who identified themselves as Croatian in general. This almost paradoxical form of connection occurred at several levels. Franjo Tudjman (created Croatian President on 30 May 1990) declared himself ready to cast off the Nazi yoke that had lain over the Croatian state since the Second World War, when Croatia had been a satellite state. According to Tudjman, this would best be achieved by destroying the memorials to the victims of the outrages committed in the earlier Croatian state. ${ }^{13}$ The process involved partly removing all trace of the exponents of the former system's symbolic capital, and partly served to increase the capital of Franjo Tudjman himself. Paradoxically enough, making a connection between the former and current states of Croatia was unnecessary, since the budding Croatian state was a new state; an opportunity for a fresh start was lost. Tudjman made television in Croatia a part of his party's (HDZ) domain as soon as he came to power. The press was also brought under control relatively effectively. ${ }^{14}$ The information arena was not neglected as a means to hold and reinforce power.

Tudjman was the one who made the equation between the two Croatian states. In contrast to casting off the Nazi yoke, he tied the old state's identity to that of the new state. The second string to Tudjman's ultranationalist bow was to manipulate the historiography of genocide of the Serbian people committed by the Ustasha state during the Second World War. The researcher Tomislav Dulić writes that Tudjman used three different arguments to downplay the atrocities committed by Ustasha. Firstly, Tudjman states that there have been Serbian

\footnotetext{
${ }^{12}$ Dimitrijevic (2000, p. 638 and notes 17 and 18).

${ }^{13}$ Udovicki and Torov (1997, p. 111).

${ }^{14}$ Balas (1997, p. 266).
} 
exaggerations; secondly, that some sources have been at fault; thirdly, that he relativises the events. ${ }^{15}$ How and to whom he catered these theses is one thing, but it does also say something about how Tudjman was structured and how his space of possibilities was constructed. Since the 1950s, he had worked on a revisionist history to reduce the blame put on the Ustasha Croatian state during World War Two. ${ }^{16}$ This was not a new idea for him, based on pure opportunism. Apparently, he did not see the actions of the Ustasha as very wrong so one can assume that he was disposed to not only forgive such actions but also consecrate them if the right situation appeared again for something similar to happen.

This resulted in morbid, but certainly, necessary countermeasures being taken by the Serbs when Serbian mass graves were dug up in the summers of 1989 and 1990 in Krajina, Croatia, to counteract Tudjman's falsification of history. ${ }^{17}$ The Krajina area in Croatia was used as a token which both politicians played on, as Tudjman wanted Croatian autonomy, and Milošević said that it was impossible with the old Serbian settlement Krajina within its borders. ${ }^{18}$ The region was an old Serbian settlement, called "the military border" where the Croatian Ustashi regime conducted genocide against Serbs during World War Two. ${ }^{19}$ After the elections in 1990, the Serb leadership in the region proclaimed the area an autonomous region (an oblast) which came to have different names during its existence.

Tudjman also denied Croatia's part in the Holocaust during the Second World War. ${ }^{20}$ In addition, Franjo Tudjman declared that the Ustasha state was a worthy predecessor to modern Croatia. ${ }^{21}$ This type of unwholesome retrospective historical connection enabled these former

${ }^{15}$ Dulić $(2009$, p. 264).

${ }^{16}$ Dulić $(2009$, p. 278).

${ }^{17}$ Loc. cit. This was mainly a success as the US policy included the ethnic cleansing of Krajina, where Serbs had lived for 500 years. The Americans saw it as "recapturing the territory from the Serbs". Allin (2002, p. 30).

${ }^{18}$ Glenny (1992, p. 37).

${ }^{19}$ Sell (2002, p. 113).

${ }^{20}$ Ramet (1999, p. 51).

${ }^{21}$ Naimark (2001, p. 154). 
criminal deeds to move from the era of the Second World War to the surface of the contemporary political agenda. Croatian units also used Ustasha insignia, which strengthened ties with the past and contributed to eradicating the difference between the present and the past. ${ }^{22}$ HDZ success came from playing on threats from Belgrade and on the surge for alternatives to communism. ${ }^{23}$ In addition, Tudjman's policies lent legitimacy to Milošević's policies, by confirming that which aggressive nationalism was saying the Serbs had been subjected to. This led to an undermining of the reputations of those who opposed Milošević in Serbia, when he was seen to be obviously right, given the context, in the light of Tudjman's actions.

Budding Serb nationalism was, paradoxically enough, the very breath of life for the politics of Tudjman in Croatia and vice versa. ${ }^{24}$ Serb nationalistic intellectuals provided further arguments along the lines of ethnicity and nation. ${ }^{25}$ Croatia had the support of the West from the very start and right through to the end of the conflict, in contrast to the rest of Yugoslavia. This is noteworthy bearing in mind what the country stood for and did; the regime was virtually a mirror image of the more vocal Serbian nationalistic politicians. These are the central elements to the understanding of the internal conditions in Yugoslavia before violence came to the surface. The same type of mutual relationship was visible between Likud and the PLO, especially under the leadership of Arafat. The latter had seen his reputation weakened among the Palestinian people, but he enjoyed an upswing during the unrest of 1996. Arafat as well as Likud needed an external enemy in order to be able to use the image in their domestic arenas. ${ }^{26}$ So, one can see that there was a drive towards radicalisation in politics before the major hostilities broke out.

In Serbian politics, Milošević could take steps towards the break-up of Yugoslavia and eventually war, much because he was not very extreme

\footnotetext{
${ }^{22}$ Naimark (2001, p. 157 (about Second World War references being used) and p. 172).

${ }^{23}$ Gagnon (2004, p. 47).

${ }^{24}$ For the interlinking connection between the politics of Tudjmans and Milosevic, see, for example, Udovicki and Torov (1997, p. 93) and Stitkovac (1997, pp. 156 and 158), also Udovicki and Stitkovac (1997, p. 174).

${ }^{25}$ Sell (2002, p. 111).

${ }^{26}$ Hammes (2006, p. 117).
} 
in comparison. Vojislav Šešelj and Vuk Drašković went on with different radical projects. On 18 June 1990, Vojislav Šešelj founded the Serbian Chetnik Movement as an attempt at a party, but authorities refused to register it as a party. ${ }^{27}$ Vuk Drašković became the leader of SPO (The Serbian Renewal Movement, Srpski Pokret Obnove) which he started. In the beginning, SPO was formed as a pyramid organisation with an "unimpeachable leader". ${ }^{28}$ Before the war in Croatia, in May 1990, the SPO wanted autonomous Serbian regions in Krajina, Istria, Dubrovnik and 4 regions in Bosnia. ${ }^{29}$ On 7 January 1990, Vuc Drašković proclaimed that the goal of his party was "the creation of a democratic, multiparty Serbian state within her historical and ethnic borders". ${ }^{30}$ From July to December 1990, one-third of SPO's statements were about the national question. Correspondingly, only $6 \%$ of SPS and DS statements concerned this. $^{31}$

The role of the Orthodox Church could be mentioned as the text deals mostly with the politics in Serbia, and the church indeed played a political role on the social field of politics in Yugoslavia. Bishop Simeon Zlokovic' was a critic of both Tudjman and Milošević. He saw them both as representatives of extremes on the right-left political scale. This was in June 1990, and Milošević was not then very much a traditional communist, but the bishop did rightly see these two actors as the symbols for extreme politics, and in hindsight, he was right. As the Orthodox Church and the myths and history of Serbia are intertwined, it is easy to see that the church had a nationalistic profile. The Orthodox Church in Serbia is by its nature tightly linked to Serbian nationalism, and vice versa. ${ }^{32}$ History is what the Orthodox Church and Serbian nationalism had in common. The Church did ask for Serbian unity in the elections of 1990 and warned against genocide of Serbs and Ustasha

\footnotetext{
${ }^{27}$ Thomas (1999, p. ix).

${ }^{28}$ Stojanovic (2000, p. 455$)$.

${ }^{29}$ Stojanovic (2000, p. 462$)$.

${ }^{30}$ Stojanovic $(2000$, p. 463$)$.

${ }^{31}$ Stojanovic (2000, p. 468).

${ }^{32}$ Ramet (2005, p. 256).
} 
in Bosnia. ${ }^{33}$ The connection between culture and land was strong in the church's rhetoric; for example, the church asked the Bosnian Serbs to stay in "their ancestral homes". 34 The church also came to be in a state of denial further on, as it denied the existence of concentration camps run by Serbs in Bosnia. 35

So, the Orthodox Church was very much linked to nationalism in Serbia. Belief certainly played a part in Croatia too. The change in the figures among declared believers in Croatia rose from 47\% in 1989 to $76 \%$ in $1996 .{ }^{36}$ In the case of the Muslim population of Croatia, one just has to mention that much of the violence imposed on these Muslims came into force just because they were Muslims. This of course moulded them together and strengthened the importance of being a Muslim in Bosnia and not just being a Bosnian. Nothing of this suggests that religion encourages ethnic cleansing. But religion was important in creating a we and by that also creating a they. This in its turn had consequences when it came to structuring Yugoslavia into a violent place during the 1990s.

During 1990, Yugoslavia as a project appeared to be a lost cause, and the alternatives grew in strength in both Serbia and Croatia. The nationalistic rhetoric increased in Croatia, but in Serbia, smaller parties followed the same road, opening up for Milošević to apply a more nationalistic approach without looking all too extreme- the latter would have scared popular support away. Worth mentioning is that it was not only the end of the Cold War that was paramount for the change taking place but the lack of a democratic heritage in the new multiparty state also played a role. Even if Yugoslavia under Tito had been a rather benevolent totalitarian state, it still was a totalitarian state which structured its population and politicians. All in all, the political field was restructured by actors whose space of possibility in the given situation had changed.

\footnotetext{
${ }^{33}$ Ramet (2005, p. 258). See also p. 262 about church resistance against Milosevic.

${ }^{34}$ Ramet (2005, p. 259).

${ }^{35}$ Ramet (2005, p. 258).

${ }^{36}$ Sekulic et al. (2006, p. 814). See also p. 818 about religion being important in both Serbian and Croatian nationalist ideology.
} 


\section{BIBLIOGRAPHY}

Allin, D. H. (2002). Nato's Balkan interventions. Routledge: Oxford.

Balas, S. (1997). "The opposition in Croatia". Burn this house. The making and unmaking of Yugoslavia. In J. Udovicki \& J. Ridgeway (Eds.). Durham: Duke University Press.

Dimitrijevic, V. (2000). Yugoslavia and the world. In N. Popov (Ed.), The road to war in Serbia: Trauma and catharsis. Budapest: Central European University Press.

Donia, R., \& Fine, J. (1994). Bosnia and Herzegovina. A tradition betrayed. London: Colombia University Press.

Dulić, T. (2009). Mapping out the wasteland: Testimonies from the Serbian commissariat for refugees in the service of Tudjman's revisionism. Holocaust and Genocide Studies, 23(2): 241-246. (Oxford).

Dulić, T., \& Kostic, R. (2010). Yugoslavs in arms: Guerilla tradition, total defence and the ethnic security dilemma. Europe-Asia Studies, 62(7): 10511072. (New York: Routledge).

Dyker, D. A., \& Vejoda, I. (1996). Yugoslavia and after. A study in fragmentation, despair and rebirth. New York: Routledge.

Gagnon, V. P. (2004). The myth of the ethnic war. Serbia and Croatia in the 1990s. Ithaca: Cornell University Press.

Glenny, M. (1992). The fall of Yugoslavia. London: Penguin Books.

Gunneriusson, H. (2002). Det historiska fültet. Svensk historievetenskap från 1920-tal till 1957. Uppsala: Studia Historica Upsaliensia.

Haffner, S. (1991). The ailing empire: Germany from bismarck to Hitler. New York: Fromm International.

Hammes, T. X. (2006). The sling and the stone: On war in the 21st century. St. Paul: Zenith Press.

Kerenji, E. (2005). Vojvodina since 1988. In S. P. Ramet \& V. Pavlakovic (Eds.), Serbia since 1989. Politics and society under Milošević and after. Seattle: University of Washington Press.

Mann, M. (2005). The dark side of democracy. Explaining ethnic cleansing. Cambridge: Cambridge University Press.

Naimark, N. M. (2001). Fires of hatred. Ethnic cleansing in twentieth-century Europe. Boston: Presidents and Fellows of Harvard College.

Pavlakovic, V. (2005). Serbia transformed? Political dynamics in the Milošević Era and after. In S. P. Ramet \& V. Pavlakovic (Eds.), Serbia since 1989. Politics and society under Milosevvić and after. Seattle: University of Washington Press.

Ramet, S. P. (1999). Balkan Babel. The disintegration of Yugoslavia from the death of tito to the war for Kosovo. Boulder: Westview Press.

Ramet, S. P. (2005). The Politics of the Serbian Orthodox Church. In Sabrina P. Ramet \& Vjeran Pavlakovic (Eds.). Seattle and London: University of Washington Press. 
Sekulic, D., et al. (2006). Ethnic intolerance and ethnic conflict in the dissolution of Yugoslavia. Ethnic and Racial Studies, 29(5): 797-827. (New York: Routledge).

Sell, L. (2002). Slobodan Milošević and the destruction of Yugoslavia. Durham: Duke University Press.

Stitkovac, E. (1997). Croatia. The first war. In J. Udovicki \& J. Ridgeway (Eds.), Burn this house. The making and unmaking of Yugoslavia. Durham: Duke University Press.

Stojanovic, D. (2000). The traumatic circle of the Serbian opposition. In N. Popov (Ed.), The road to war in Serbia. Tramma and catharsis. Budapest: Central European University Press.

Thomas, R. (1999). Serbia under Milošević politics in the 1990s. London: C Hurst \& Co Publishers Ltd.

Udovicki, J., \& Stitkovac, E. (1997). Bosnia and Hercegovina: The second war burn this house. In J. Udovicki \& J. Ridgeway (Eds.), The making and unmaking of Yugoslavia. Durham: Duke University Press.

Udovicki, J. \& Torov, I. (1997). "The interlude". Burn this house. The making and unmaking of Yugoslavia. In J. Udovicki \& J. Ridgeway (Eds.). Durham: Duke University Press.

Open Access This chapter is licensed under the terms of the Creative Commons Attribution 4.0 International License (http://creativecommons.org/licenses/ by $/ 4.0 /$ ), which permits use, sharing, adaptation, distribution and reproduction in any medium or format, as long as you give appropriate credit to the original author(s) and the source, provide a link to the Creative Commons license and indicate if changes were made.

The images or other third party material in this chapter are included in the chapter's Creative Commons license, unless indicated otherwise in a credit line to the material. If material is not included in the chapter's Creative Commons license and your intended use is not permitted by statutory regulation or exceeds the permitted use, you will need to obtain permission directly from the copyright holder.

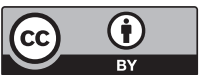

